\title{
Heterogeneity in the gene locus for steroid 21-hydroxylase deficiency
}

GILlian RUMSBY*, ANGElA H L FIEldER, William M HAgUE, AND JOHN W HONOUR

From the Department of Clinical Biochemistry, Institute of Child Health, London WC1N 1EH; Department of Immunology, Royal Postgraduate Medical School, Hammersmith Hospital, London W12 0HS; and Cobbold Laboratories, The Middlesex Hospital, London WIN 8AA.

SUMMARY DNA was analysed from 33 patients with congenital adrenal hyperplasia due to ज्ञ steroid 21-hydroxylase deficiency. In each case Southern blots were prepared from a number of 6 restriction enzyme digests and hybridised with probes for both the 21-hydroxylase and the $\mathcal{E}$ adjacent fourth component of complement (C4).

Evidence for deletion of the active 21-hydroxylase gene (CYP21B) was found in 13 cases and in 10 of these the deletion included the adjacent C4B gene, leading to a hybrid CYP21A/CYP21B $\vec{~}$ gene. Deletion of CYP21B alone was found in one patient, the remaining two cases appearing to $\frac{\mathbb{D}}{\mathrm{O}}$ have the active gene replaced by the inactive pseudogene. Duplications of the CYP21A-C4B region and deletion of the pseudogene are also described. In a further 12 cases no gross abnormality could be found.

The genes coding for the steroid 21-hydroxylase enzyme (EC 1.14.99.10, CYP21) are located on the short arm of chromosome $6,3^{\prime}$ to the genes coding for the fourth component of complement, C4A and C4B. Deficiency of this enzyme leads to congenital adrenal hyperplasia (CAH) and has been shown to be caused by a heterogeneous range of defects, including deletions of the active (21-hydroxylase B)

*Present address: Department of Chemical Pathology. Royal Marsden Hospital, London SW3 6JJ.

Received for publication 9 March 1988.

Accepted for publication 31 March 1988. gene $^{12}$ and possible point mutations and gene conversions. ${ }^{34}$ This paper summarises the finding in a group of 33 patients with 21-hydroxylase deficiency from 31 families.

\section{Patients}

The majority of patients had presented in the neonatal period as salt losers $(\mathrm{SL}, \mathrm{n}=24)$ or as simple virilisers $(\mathrm{SV}, \mathrm{n}=3)$. Six had presented as late onset (LO) cases at ages ranging from five to 20 years.

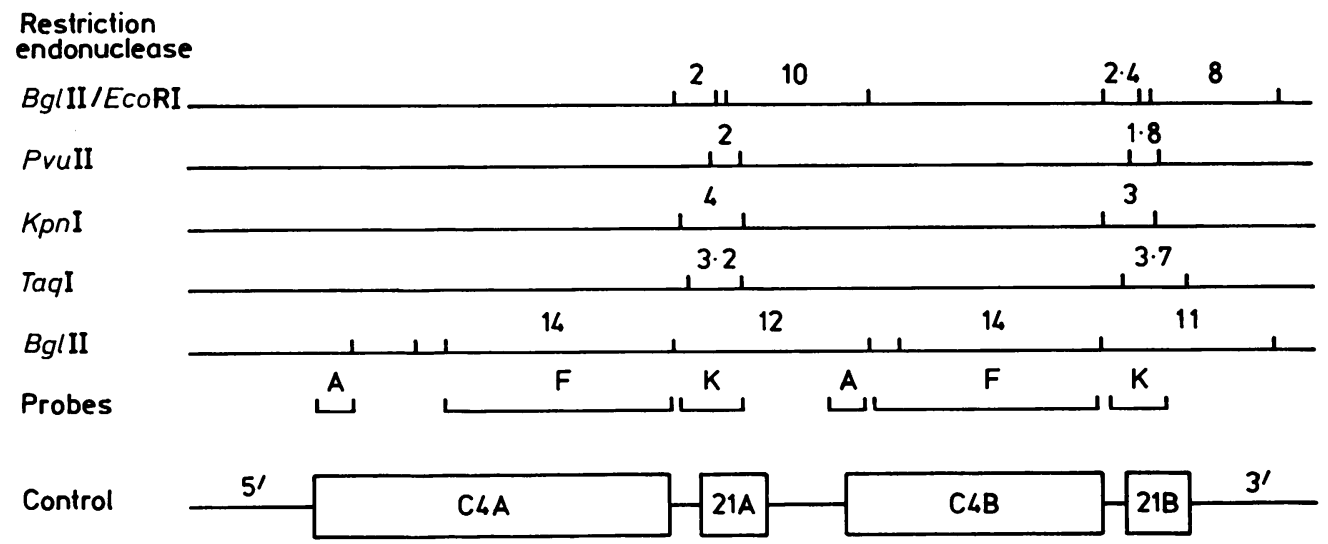

FIG 1 Simplified restriction enzyme map of the C4/21-hydroxylase region of chromosome 6. 


\section{Methods}

Genomic DNA was isolated from peripheral blood leucocytes by the method of Bell et al. ${ }^{5}$ Samples of $10 \mu \mathrm{g}$ were digested with restriction endonucleases according to the manufacturer's instructions (Pharmacia Ltd). Digests were separated on $0.75 \%$ agarose gels, treated according to Wahl et al, ${ }^{6}$ and blotted onto nitrocellulose. ${ }^{7}$ Hybridisation conditions and probes used were as previously described. $^{1}$ Their location in the C4/21-hydroxylase gene region is shown in fig 1 . C4 allotyping was carried out after neuraminidase treatment of EDTA plasma. ${ }^{8}$

\section{Results}

Interpretation of results required the use of all probes and a variety of restriction endonucleases. The fragments these produce are shown in fig 1 . Most useful was the analysis of TaqI digests with both probes $A$ and $K$ which gave information on the C4 (A and B) and 21-hydroxylase (CYP21A and B) genes respectively, as described by Schneider et al. ${ }^{9}$ In addition, a double digest of DNA with the enzymes $B g l \mathrm{II}$ and $E c o$ RI, as previously described, ${ }^{1}$ gives information on both the $5^{\prime}$ and $3^{\prime}$ ends of each 21-hydroxylase gene.

Twelve patients (10 SL, $2 \mathrm{LO}$ ) had intact $\mathrm{C} 4$ and 21-hydroxylase genes on both chromosomes, giving a normal pattern with all enzymes used (fig 2, lane 1).

Homozygous deletions of the active CYP21B locus in this group of patients are rare (1/33) (fig 2, lane 2). This SL patient had a deletion extending from the $3^{\prime}$ end of the $21 \mathrm{~A}$ gene to the $3^{\prime}$ end of the 21B gene, including the $\mathrm{C} 4 \mathrm{~B}$ locus, and has been previously described. ${ }^{1}$ An apparent heterozygous deletion of the same region occurred in a further nine cases (1 SV and $8 \mathrm{SL}$ ) (fig 2, lane 3). This was associated with an HLA-B47 haplotype in only two of these cases.

One SL patient appeared to have a deletion of the 21B gene alone. The results of a TaqI digest using probes $A$ and $K$ are shown in fig 2, lane 4 . No $3.7 \mathrm{~kb}$ band is present with probe $\mathrm{K}$, while probe A shows three bands of $7 \mathrm{~kb}, 6 \mathrm{~kb}$, and $5.4 \mathrm{~kb}$ respectively, the first being of approximately twice the intensity of each of the other two. This indicates that not only is the C4B locus intact, but that both a 'short' and 'long' C4B gene are present (bands at $6 \mathrm{~kb}$ and 5.4 kb). ${ }^{9}$ The $3 \mathrm{~kb} K p n$ band was also absent. The data suggest either that both chromosomes have a single deleted CYP21B or that there are two CYP21A genes present on each chromosome and no CYP21B gene, that is, gene conversion has occurred. In this particular subject, the $3^{\prime}$ end of the CYP21B gene appears to be unchanged, as a double digest using
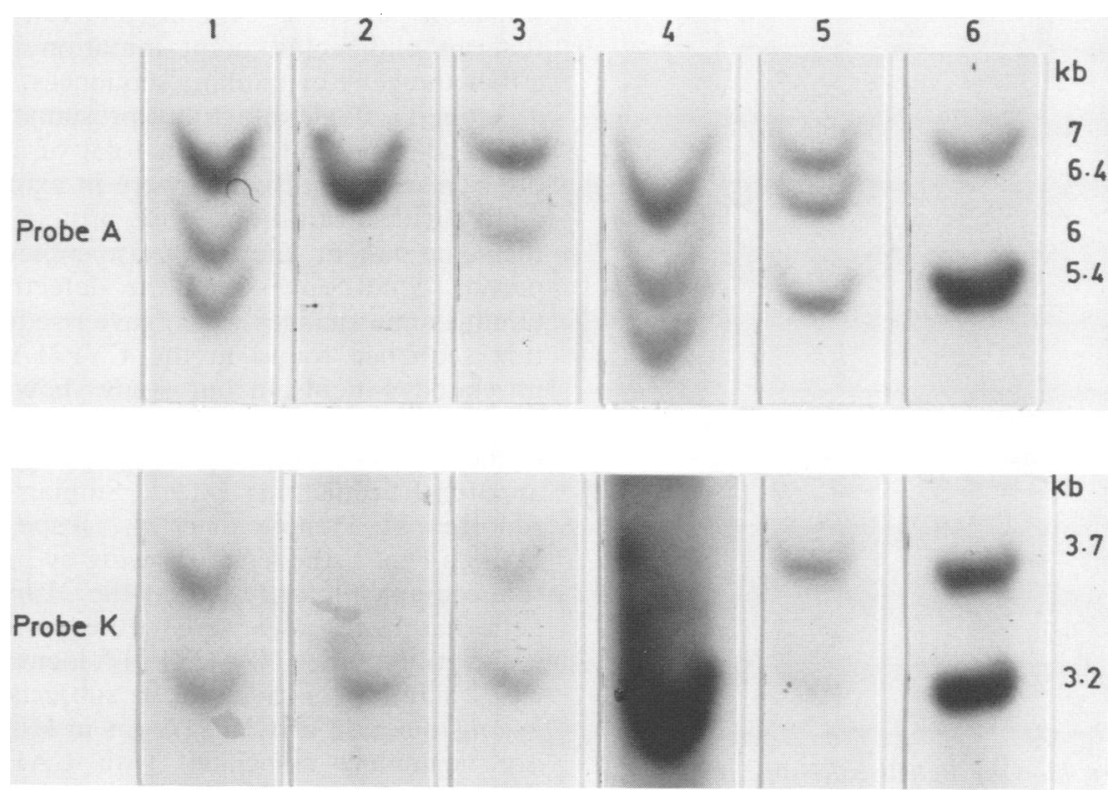

FIG 2 Southern blots of TaqI digests of DNA from six patients with 21-hydroxylase deficiency. 
$B g l \mathrm{II} / E c o$ RI showed a deletion of the $2.4 \mathrm{~kb}$ band located at the $5^{\prime}$ end of $21 \mathrm{~B}$ and not of the $3^{\prime} 8 \mathrm{~kb}$ band (fig 3a). One other SL case was heterozygous for a 'deleted'/"converted' CYP21B (fig 3b).

Two patients (1 SL, $1 \mathrm{SV}$ ) in whom the CYP21B gene appeared to be intact had the C4A-CYP21A genes deleted on one chromosome. This led to a reduced intensity of the $3.2 \mathrm{~kb} T a q \mathrm{I}, 4 \mathrm{~kb} K p n \mathrm{I}$, and $10 \mathrm{~kb} E c o \mathrm{RI} / B g / \mathrm{II}$ bands with probe $\mathrm{K}$, in addition to the presence of the $6.4 \mathrm{~kb}$ TaqI fragment detected with probe $\mathrm{A}$, a marker for deletion of the C4A gene" (fig 2, lane 5). C4 protein typing confirmed the presence of a C4A null allele.

A duplication of the 21A-C4B locus was found in two LO patients, as expected in association with HLA-B14, DR1. This gave the pattern of a heterozygous deletion of $21 \mathrm{~B}$, that is, reduced intensity of the $3.7 \mathrm{~kb}$ Taq $, 3 \mathrm{~kb} K p n \mathrm{I}, 8$ and $2.4 \mathrm{~kb}$ $B g / \mathrm{II} / E c o \mathrm{RI}$, and $11 \mathrm{~kb} B g / \mathrm{II}$ fragments, as detected with probe $\mathrm{K}$. With probe $\mathrm{A}$, however, the bands

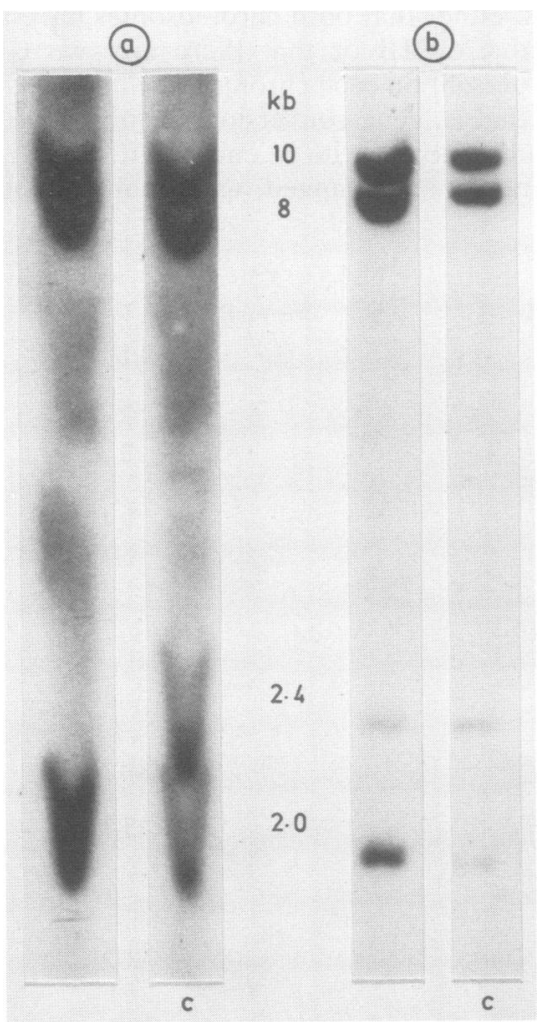

FIG 3 Southern blots of BglII/EcoRI digests of DNA from patients with 21-hydroxylase deficiency compared with controls (c). corresponding to the $5^{\prime}$ region of the $\mathrm{C} 4 \mathrm{~B}$ gene were of greater intensity than C4A with both the TaqI (fig 2 , lane 6) and $B g l I I$ digests (data not shown). $\mathrm{C} 4$ protein typing of one family showed the presence of three $\mathrm{C} 4 \mathrm{~B}$ genes in the affected child (C4A2, Q0B1,1,2), two of which had been inherited from the mother on a single chromosome. One other LO patient showed similar results with probe is $\mathrm{K}$, that is, reduced intensity of the 2.4 and $8 \mathrm{~kb} \vec{\circ}$ bands after $B g l \mathrm{II} / E c o$ RI double digest. However, no evidence for duplication, crossover, or recom- $\vec{\omega}$ bination was found either with probe $\mathrm{A}$ or $\mathrm{C} 4 \mathrm{~S}$ protein allotyping. One must therefore assume that this is a true deletion of the whole CYP21B gene.

The digests from the remaining four $(1 \mathrm{LO}, 1 \mathrm{SV}$, $2 \mathrm{SL}$ ) patients appeared to show reduced intensity of one 21-hydroxylase gene with one enzyme but not with the others. This may be the result of loss of a $\mathrm{O}$ single restriction enzyme site which can only be confirmed by sequencing the CYP21A and CYP21B os genes in these cases.

\section{Discussion}

The most important finding in this study is the range $\vec{\bullet}$ of genetic defects which can give rise to the clinices $\infty$ presentation of 21-hydroxylase deficiency. The interpretation of results in these patients is difficut and requires the use of more than one restriction enzyme and probes for both $\mathrm{C} 4$ and 21-hydroxylase.

In those cases in which a normal restriction fragment pattern is evident, one can only assume that an undetected point mutation is present in either the gene or flanking sequences. Rodrigues $e t$ $a l^{3}$ cloned a single intact, but presumably defective, CYP21B gene and found a total of 11 nucleotide differences, two of which were in exons leading to amino acid substitutions in the protein molecule. In the same patient, there was also some evidence for partial 'gene conversion', the defective 21B containing some changes which gave rise to the nucleotide sequence found in the CYP21A gene. Two unrelated patients in our study show evidence of $\mathrm{S}$ possible gene conversion; in both the characteristics of the $5^{\prime}$ end of the 21B gene are missing, the $3^{\prime}$ end apparently remaining intact. Similar results were $N$ reported by Donohoue et al, ${ }^{4}$ Jospe et al, ${ }^{10}$ and Harada $e t$ al, ${ }^{11}$ the latter showing by partial nucleo- $\mathcal{O}$ tide sequencing analysis that the 21 -hydroxylase $\mathrm{B} \underset{\mathrm{N}}{\mathrm{N}}$ gene has been converted to the pseudogene. $\sigma$

Deletion of the C4A-CYP21A locus in two of our 0 cases may be coincidental, as subjects with homo- $\overparen{D}$ zygous deletion of CYP21A (as in HLA-B8, DR3) $\stackrel{\mathcal{C}}{?}$ are negatively associated with $\mathrm{CAH}{ }^{12}$ An un- 0 detected fault could lie in the CYP21B genes present. 
The HLA-B14, DR1 haplotype associated with late onset $\mathrm{CAH}$ has been shown to have a duplication of the $C 4 B^{13}$ and CYP21A ${ }^{14}$ loci. These findings are confirmed here. It is still not clear, however, why such a duplication should lead to defective enzyme activity in the presence of an apparently normal 21B gene.

In all patients assigned a deleted CYP21B gene in this and our previous study, 'the deletion was confirmed using several enzymes. With one exception the deletion included the $\mathrm{C} 4 \mathrm{~B}$ gene (confirmed with probe A). The gene is thus a hybrid with $5^{\prime}$ characteristics of the CYP21A and those of the CYP21B gene at the $3^{\prime}$ end, as previously described. ${ }^{15}$ This point was overlooked by Matteson et al ${ }^{16}$ who showed the $3.7 \mathrm{~kb}$ Taq fragment to be absent but after other enzyme digests failed to confirm deletion of CYP21B.

In conclusion, gene deletion, conversion, and duplication have been found in 21 of the cases of 21hydroxylase deficiency described here, with the possibility in the remaining 12 cases of point mutations in the 21-hydroxylase gene.

We are grateful to Dr D B Grant, Dr C G D Brook, and Professor H S Jacobs for allowing us to study their patients. WMH was generously supported as a Clinical Research Fellow by the Frances and Augustus Newman Foundation.

\section{References}

1 Rumsby G. Carroll MC, Porter RR. Grant DB. Hjelm M. Deletion of the steroid 21-hydroxylase and complement $\mathrm{C} 4$ genes in congenital adrenal hyperplasia. J Med Genet 1986:23: 204-9.

2 White PC, New MI. Dupont B. HLA-linked congenital adrenal hyperplasia results from a defective gene encoding a cytochrome P-450 specific for steroid 21-hydroxylation. Proc Natl Acad Sci USA 1984:81:7505-9.

${ }^{3}$ Rodrigues NR. Dunham I. Yung Yu C. Carroll MC. Porter RR.
Campbell RD. Molecular characterisation of the HLA-linked steroid 21-hydroxylase $B$ gene from an individual with congenital adrenal hyperplasia. EMBO J 1987:6:1653-61.

+ Donohouc PA. Van Dop C. McClcan RH. White PC. Jospe N. Migeon CJ. Gene conversion in salt-losing congenital adrenal hyperplasia with absent complement C4B protein. J Clin Endocrinol Metab 1986:62:995-10(02.

5 Bell GI. Karam JH. Rutter WJ. Polymorphic DNA region adjacent to the 5' end of the human insulin gene. Proc Natl Acad Sci USA 1981:78:5759-63.

- Wahl GM. Stern M. Stark GR. Efficient transfer of large DNA fragments from agarose gels to diazobenzyloxymethyl paper and rapid hybridisation by using dextran sulphate. Proc Natl Acad Sci USA 1979:76:3863-7.

7 Southern EM. Detection of specific sequences among DNA fragments separated by gel electrophoresis. J Mol Biol 1975:98: 503-17.

" Mauff G. Alper CA. Awdeh ZL, et al. Statement on the nomenclature of human C4. Immunobiologv 1983:164:184-91.

"Schncider PM. Carroll MC. Alper CA. et al. Polymorphism of the human complement $\mathrm{C} 4$ and steroid 21 -hydroxylase genes. $J$ Clin Invest 1986:78:650-7.

11 Jospe N, Donohoue PA, Van Dop C, MacClean RH. Bias WB. Migeon CJ. Prevalence of polymorphic 21-hydroxylase gene (CA21HB) mutations in salt-losing congenital adrenal hyperplasia. Biochem Biophys Res Commun 1987:142:798-8()4.

1 Harada F, Kimura A. Iwanaga T, et al. Gene conversion like events cause steroid 21-hydroxylase deficiency in congenital adrenal hyperplasia. Proc Natl Acad Sci USA 1987:84:8(191-4.

12 Carroll MC. Palsdottir A. Belt KT. Porter RR. Deletion of complement $\mathrm{C} 4$ and steroid 21-hydroxylase genes in HLA class III region. EMBO J 1985:4:2547-52.

13 Carroll MC, Belt KT. Palsdottir A. Porter RR. Structure and organisation of the C4 genes. Philos Trans $R$ Soc Lond /Biol] 1984:306:379-88.

it Garlepp MJ. Wilton AN. Dawkins RL. White PC. Rearrangement of 21-hydroxylase genes in disease-associated MHC supratypes. Immunogenetics 1986:23:100-5.

15 White PC, New M. Dupont B. Congenital adrenal hyperplasia. $N$ Engl J Med 1987:317:1414-5.

16 Matteson KJ. Phillips JA. Miller WL. et al. P450XXI (steroid 21-hydroxylase) gene deletions are not found in family studies of congenital adrenal hyperplasia. Proc Natl Acad Sci USA 1987:84:5858-62.

Correspondence and requests for reprints to Dr J W Honour, Cobbold Laboratories, Middlesex Hospital, Mortimer Street, London W1N 8AA. 